\title{
PERBEDAAN KEMANDIRIAN BELAJAR SISWA ANTARA MODEL BLENDED LEARNING BERBASIS MASALAH DAN KONVENSIONAL DI SMP
}

\author{
Khairul Ramadhani Daulay ${ }^{1}$, Mulyono $^{2}$, Mariani $^{3}$
}

\begin{abstract}
ABSTRAK
Penelitian ini bertujuan untuk: 1) mengidentifikasi perbedaan kemandirian belajar siswa setelah menerapkan model blended learning berbasis masalah dan konvensional, 2) melihat interaksi antara model pembelajaran dan kemampuan awal matematika terhadap kemandirian belajar siswa. Populasi dalam penelitian ini adalah seluruh siswa SMP Swasta Imelda Medan dan sampel dalam penelitian ini adalah siswa kelas VIII SMP sebanyak 61 orang.Penelitian ini merupakan penelitian eksperimen semu. Instrumen penelitian ialah angket dan observasi aktivitas siswa selama pembelajaran.Data yang dikumpulkan tersebut kemudian dianalisis dengan menggunakan ANAVA dua jalur pada program SPSS. Berdasarkan hasil analisis data dapat disimpulkan bahwa: 1) terdapat perbedaan yang signifikan antara model blended learning berbasis masalah dan pembelajaran konvensional terhadap kemandirian belajar siswa. 2) Terdapat interaksi antara model pembelajaran dan kemampuan awal matematika terhadap kemandirian belajar siswa.
\end{abstract}

Kata Kunci: model blended learning berbasis masalah, pembelajaran konvensional, kemandirian belajar

\section{PENDAHULUAN}

Pendidikan merupakan hal yang penting dan mendasar bagi setiap manusia. Pendidikan saat ini telah memiliki banyak sekali mengalami banyak perubahan dari segi kurikulum sampai guru dituntut untuk menggunakan media dalam proses pembelajaran. Menyikapi perubahan ini, guru bukan hanya sekedar mengajar (transfer of knowledge) melainkan harus menjadi manager dalam hal belajar.

Keberhasilan pendidikan dalam berbagai jenjang ditentukan oleh banyak faktor seperti siswa, tenaga kependidikan (guru atau dosen), kurikulum atau program pendidikan, manajemen, fasilitas, dukungan dana, partisipasi masyarakat dan dunia kerja. Oleh karena itu, pendidikan seharusnya dijalankan dengan sebaik-baiknya sehingga tujuan pendidikan dapat terwujud.

Dalam mewujudkan tujuan pendidikan nasional, pemerintah melalui sekolah dapat membekali siswa dengan berbagai mata pelajaran yang harus dikuasai.Salah satu mata pelajaran yang memiliki peranan penting dalam aspek kehidupan untuk mewujudkan tujuan pendidikan adalah matematika.Namun kenyataan yang ada di lapangan, pembelajaran matematika yang dilaksanakan belum sesuai dengan yang diharapkan. Dalam hal ini pembelajaran matematika lebih cenderung berfokus pada buku teks, masih sering pula guru matematika

${ }^{1}$ Corresponding Author:Khairul Ramadhani Daulay

Program Magister Pendidikan Matematika, Universitas Negeri

Medan, Medan, 20221, Indonesia

E-mail: daniramadhani66@gmail.com

${ }^{2}$ Co-Author: Mulyono \& Mariani

Program Studi Pendidikan Matematika, Universitas Negeri Medan, Medan, 20221, Indonesia masih terbiasa dengan kebiasaan mengajarnya menggunakan langkah-langkah pembelajaran seperti: menyajikan materi pembelajaran, memberikan contohcontoh soal dan meminta siswa mengerjakan soal-soal latihan yang terdapat dalam buku teks. Hal ini didukung oleh Ruseffendi (2006: 328) yang menyatakan bahwa "selama ini dalam proses pembelajaran matematika di kelas, pada umumnya siswa mempelajari matematika hanya diberi tahu oleh gurunya bukan melalui kegiatan eksplorasi”. Itu semua mengarah kepada siswa tidak aktif dalam belajar, selain itu proses pembelajaran seperti ini akan memperoleh kemungkinan kemampuan matematis siswa sulit berkembang.

Kemandirian belajar menuntut siswa untuk memulai usaha belajar dengan sendirinya tanpa tergantung pada guru, orang tua maupun orang lain yang ada dilingkungan nya. Proses belajar mandiri ini memberikan siswa kesempatan yang luar biasa untuk mempertajam kesadaran mereka akan lingkungan mereka.

Bandura (Heris Hendriana, Euis Eti Rohaeti dan Utari Sumarmo, 2017) mendefinisikan kemandirian belajar sebagai kemampuan memantau prilaku sendiri, dan merupakan kerja-keras personalitas manusia. Strategi kemandirian belajar memuat kegiatan yaitu mengevaluasi diri, mengatur dan mentransformasi, menetapkan tujuan dan rancangan, mencari informasi, mencatat dan memantau, menyusun lingkungan, mencari bantuan sosial, dan me-review catatan.

Kemandirian belajar adalah suatu keterampilan belajar yang dalam proses belajar individu didorong, dikendalikan, dan di nilai oleh diri individu itu sendiri (Lilik dalam Jumaisyaroh, Napitupulu dan Hasratuddin, 2014). Pentingnya kemandirian dalam belajar matematika karena tuntutan kurikulum agar siswa dapat menghadapi persoalan di dalam kelas 
maupun di luar kelas yang semakin kompleks dan mengurangi ketergantungan siswa dengan orang dalam kehidupan sehari-hari (Fauzi, 2011: 111). Namun, saat ini kenyataannya bahwa kemandirian belajar belum tersosialisasi dan berkembang di kalangan peserta didik, mereka menganggap bahwa guru satu-satunya sumber ilmu sehingga menyebabkan siswa memiliki ketergantungan dengan orang lain terutama kepada guru.

Saat ini, dunia tengah memasuki era revolusi industri 4.0.atau revolusi industri dunia ke-empat dimana teknologi telah menjadi basis dalam kehidupan manusia. Diharapkan dengan pemanfaatan teknologi informasi dan komunikasi pola pikir pembelajaran dapat bergeser dari berpusat pada guru (teacher centered) menjadi berpusat pada peserta didik (student centered) dan dengan hal ini diharapkan kemandirian belajar siswa dapat berkembang dengan baik.

Dalam kurikulum 2013 sendiri penggunaan teknologi dalam pembelajaran menjadi sesuatu yang sangat dianjurkan.Proses pembelajaran pada kurikulum 2013 menuntut siswa untuk berpartisipasi aktif serta memberi ruang yang cukup untuk kreativitas, minat dan bakat siswa.

Sesuai dengan perkembangan zaman maka dalam proses pembelajaran telah banyak dikembangkan dengan mengoptimalkan pembelajaran seperti $e$ learning. Pembelajaran e-learning merupakan teknologi pembelajaran yang berperan penting untuk siswa mengakses pembelajaran secara jarak jauh. Dengan menggunakan pembelajaran e-learning ini juga diharapkan menjadi suatu pembelajaran mandiri bagi siswa.

Berdasarkan permasalahan diatas, maka diperlukan model pembelajaran yang mampu meningkatkan kemandirian belajar siswa. Salah satu model pembelajaran yang kreatif, inovatif, dan efektif dalam meningkatkan kemampuan pemecahan masalah dan kemandirian belajar siswaadalah Blended Learning.Pembelajaran Blended Learning menjadi bagian dari upaya untuk menggunakan kemanjuan teknologi dalam peningkatan mutu pembelajaran.Kemajuan teknologi yang pesat memberikan pengaruh terhadap perubahan dunia pendidikan dan pembelajaran.

Menurut Sjukur (Aprilia, 2015: 41) mengatakan bahwa Blended Learning adalah kombinasi pembelajaran tradisional dan lingkungan pembelajaran elektronik.Blended Learning menggabungkan aspek pembelajaran berbasis web/ internet, streaming video, komunikasi audio synchronouos dan asynchronouos dengan pembelajaran tradisional atau tatap muka.Blended Learning pada dasarnya merupakan gabungan keunggulan pembelajaran yang dilakukan secara tatap muka (face to face learning) dan secara virtual (e-learning).

Blended learning mengintegrasikkan pembelajaran yang inovatif dengan memanfaatkan kemajuan teknologi berupa pembelajaran online dan meningkatkan partisipasi positif siswa dari pada pembelajaran biasa. Agar pelaksanaan model Blended learning lebih bermakna maka diperlukan pembelajaran yang mampu memfasilitasi siswa kearah tersebut. Pembelajaran berbasis masalah dirasa mampu untuk mengarahkan siswa untuk mendapatkan proses belajar bermakna.

Hmelo-Silver dan Barrow (2006) mengungkapkan bahwa masalah dalam pembelajaran berbasis masalah adalah masalah yang tidak terstruktur (ill-structure), atau kontekstual dan menarik (contextual and engaging), sehingga meransang siswa untuk bertanya dari berbagai perspektif.Pembelajaran berbasis masalah merupakan pembelajaran yang menganut paham kontruktivisme.Paham kontruktivisme memandang bahwa siswa membangun suatu pengetahuan didasarkan pada pengalamannya yang dimiliki oleh masing-masing individu. Sehingga guru tidak secara langsung memberikan pengetahuannya kepada siswa, melainkan siswa sendiri yang harus berusaha membangun pengetahuannya melalui pastisipasi aktif dalam proses pembelajaran.

Berdasarkan permasalahan diatas peneliti mempertimbangkan perlunya melihat sejauh mana dampak model Blended Learning berbasis masalah terhadap kemampuan pemecahan masalah dan kemandirian belajar siswa. Sehingga dalam penelitian ini akan diuraikan lebih lanjut mengenai "Perbedaan Kemandirian Belajar Siswa Antara Model Blended Learning Berbasis Masalah dan Konvensional Di SMP”.

\section{KAJIAN TEORITIS}

\subsection{Kemandirian Belajar}

Belajar mandiri bukan berarti belajar sendiri.Seringkali orang menyalah artikan belajar mandiri sebagai belajar sendiri. Menurut kamus besar Bahasa Indonesia (Depdiknas, 1988: 625) kemandirian adalah keadaan dapat berdiri sendiri tanpa bergantung pada orang lain.

Menurut Chaplin (2002: 4), outonomi adalah kebebasan individu manusia untuk memilih, untuk menjadi kesatuan yang bisa memerintah, menguasai dan menentukan dirinya sendiri. Sedangkan Seifert dan Hoffnung (1994: 5) mendefinisikan outonomi atau kemandirian sebagai "the ability to govern and regulate one's own thoughts, feelings, and actions freely and responsibly while overcoming feelings of shame and doubt".Dengan demikian dapat dipahami bahwa kemandirian atau otonomi adalah usaha untuk mengendalikan dan mengatur pikiran, perasaan dan tindakan sendiri secara bebas serta berusaha sendiri untuk mengatasi perasaan-perasaan malu dan keraguraguan.

Jadi, yang dimaksudkan dengan kemandirian adalah sikap tanggung jawab seseorang dengan menyadari akan potensi dan mau mengembangkannya sebagai bekal di masa depan. Memang, dalam kehidupan manusia terkandung asas tolong-menolong dan gotong- 
Vol. 13, No.2, Desember 2020

royong antar sesama, tetapi hanya sebatas pada hal-hal yang bersifat umum, tidak sampai pada persoalanpersoalan prinsip, seperti ekonomi, rumah tangga atau dalam belajar.

\subsection{Model Blended Learning}

Blended learning berasal dari kata blended (perpaduan) dan learning (pembelajaran). Dengan kata lainblended learning dapat dimaknai sebagai pembelajaran kombinasi, yaitu kombinasi pembelajaran secara tatap muka di kelas dan pembelajaran secara online dengan menggunakan aplikasi komputer yang tersambung dengan internet. Beberapa ahli mendefinisikan blended learning dengan redaksi yang berbeda-beda, tetapi dalam konsep yang sama atau hampir sama.

Whitelock dan Jelfs (2003) memberikan beberapa definisi mengenai blended learning, yaitu (1) kombinasi antara pembelajaran tradisional dengan pendekatan pembelajaran berbasis web, (2) kombinasi dari media dan tools dalam lingkungan e-learning, (3) kombinasi dari beberapa pendekatan pembelajaran, penggunaan teknologi pembelajaran.

Charman (2005) menjelaskan bahwa blended learning merupakan pendekatan pembelajaran yang menggabungkan pembelajaran konsensional (tatap muka) dan pembelajaran jarak jauh dengan sumber belajar online dengan berbagai pilihan media (teks, gambar, diagran, suara, vedeo) yang dapat diakses oleh guru dan siswa dari internet.

\subsection{Model Pembelajaran Berbasis Masalah}

Menurut Arends (dalam Trianto, 2009), pembelajaran berbasis masalah (Problem Based Learning) merupakan suatu pendekatan pembelajaran dimana siswa mengerjakan permasalahan yang autentik dengan maksud untuk menyusun pengetahuan mereka sendiri, mengembangkan inkuiri dan keterampilan berpikir tingkat lebih tinggi, mengembangkan kemandirian, dan percaya diri.

Pembelajaran berbasis masalah merupakan suatu pendekatan pembelajaran yang melibatkan masalah nyata sebagai suatu acuan bagi siswa untuk memperoleh pengetahuan dan konsep yang esensial serta keterampilan dalam memecahkan suatu masalah. Oleh sebab itu, model pembelajaran berbasis masalah merupakan salah satu model pembelajaran yang efektif digunakan untuk melatih proses berpikir tingkat tinggi siswa. Sejalan dengan pendapat Lestari dan Yudhanegara (2015) mengemukakan bahwa pembelajaran berbasis masalah merupakan model pembelajaran yang menghadapkan siswa pada suatu masalah sehingga siswa dapat mengembangkan kemampuan berpikir tingkat tinggi dan keterampilan penyelesain masalah serta memperoleh pengetahuan baru terkait dengan permasalahan tersebut.

\section{METODE PENELITIAN}

Penelitian ini termasuk dalam penelitian eksperimen semu (quasi experiment).Pada eksperimen semu tidak dapat dilakukan pengontrolan terhadap semua variabel luar yang mempengaruhi jalannya ekperimen.

Sampel dalam penelitian ini yaitu kelas VIII-A dan VIII-B. Kelas VIII-A sebagai kelas eksperimen dengan perlakuan pembelajaran blended learning berbasis masalah dan kelas VIII-B sebagai kelas kontrol yang diberi perlakuan pembelajaran konvensional.

Variabel dalam penelitian ini terdiri dari dua jenis variabel yaitu variabel bebas dan variabel terikat. Pada penelitian ini, yang menjadi variabel bebas adalah model blended learning berbasis masalah dan pembelajaran konvensional. Variabel terikat dalam penelitian ini adalah kemandirian belajar siswa, serta variabel penyerta dalam penelitian ini adalah kemampuan awal siswa.Kemampuan awal siswa ditunjukkan oleh nilai ulangan yang telah diperoleh.

\section{HASIL PENELITIAN}

\section{Data Hasil Tes Kemampuan Awal Matematika}

Kemampuan awal matematika (KAM) adalah pengetahuan yang dimiliki siswa sebelum pembelajaran berlangsung. Kemampuan awal matematika merupakan pondasi sebagai modal dasar untuk pembentukan konsep baru dalam pembelajaran. Tujuan dari kemampuan awal matematika ini adalah untuk mengetahui kemampuan matematika siswa yang tinggi dan rendah sebelum diterapkan pembelajaran baik pada kelas eksperimen dan kontrol. Kemampuan awal matematika siswa diukur melalui data yang telah dikumpulkan berdasarkan tes diagnostik yang telah diberikan kepada kedua kelas.

Hasil rangkuman rata-rata dan simpangan baku KAM seperti yang tertera pada Tabel 1 berikut ini:

\section{Tabel 1Deskripsi Nilai KAM Siswa}

\begin{tabular}{|c|c|c|c|c|c|c|}
\hline Kelas & Skor Ideal & $\mathrm{N}$ & $x_{\min }$ & $x_{\text {moke }}$ & $\bar{X}$ & SD \\
\hline Eksperimen & \multirow{2}{*}{100} & 27 & 46 & 34 & 56,85 & 13,67 \\
\hline Kontrol & & 27 & 40 & 30 & $5:, 96$ & 11,45 \\
\hline Total/Rata-rata & 100 & 54 & 42 & 82 & 64,41 & 12,56 \\
\hline
\end{tabular}

Berdasarkan perhitungan dengan menggunakan uji$\mathrm{t}$ pada taraf $\alpha=0,05$ diperoleh $\mathrm{t}_{\text {hitung }}$ sebesar 1,344 sedangkan $t_{\text {tabel }}$ sebesar 2,004.Karena $t_{\text {hitung }}<t_{\text {tabel }}$ yaitu sehingga hipotesis nol diterima. Hal ini menunjukkan bahwa kedua kelompok data kedua kelas memiliki kemampuan yang sama.

Selanjutnya dilakukan pengelompokkan kemampuan awal matematika siswa (tinggi dan rendah) dibentuk berdasarkan KAM siswa.Untuk siswa yang memiliki KAM $\geq \bar{X}+S D$ dikelompokkan dalam kemampuan tinggi, sedangkan siswa yang 
memiliki KAM $\leq \bar{X}-S D$ dikelompokkan dalam kemampuan rendah. Untuk kelas model blended learning berbasis masalah dengan $\bar{X}=66,85$ dan SD $=13,67$ sehingga $\bar{X}+S D=80,52$ dan $\bar{X}-S D=53,17 \quad$ Sedangkan untuk kelas pembelajaran konvensional nilai $\bar{X}=61,96$ dan SD $=11,45$ sehingga $\bar{X}+S D=73,42$ dan $\bar{X}-S D=50,51$.

\section{Deskripsi Kemandirian Belajar Siswa Setelah Diberi Perlakuan}

Setelah diberi perlakuan penerapan model pembelajaran dikedua kelas, maka diberikan angket kemandirian belajar siswa untuk melihat seberapa besar kemandirian belajar siswa setelah diberi perlakuan model pembelajaran. Adapun deskripsi hasil kemandirian belajar setelah diberi perlakuan disajikan pada Tabel 2 berikut ini:

Tabel 2. Deskripsi Kemandirian Belajar Siswa Setelah Diberi Perlakuan

\begin{tabular}{|c|c|c|c|c|c|c}
\hline Kelas & Skor Ideal & $\mathrm{N}$ & $x_{\text {min }}$ & $x_{\text {maks }}$ & $\bar{X}$ & SD \\
\hline Eksperimen & 100 & 27 & 52 & 96 & 79,29 & $: 3,42$ \\
\cline { 1 - 4 } \cline { 5 - 7 } Kontrol & & & 48 & 89 & 71,07 & $: 1,96$ \\
\hline
\end{tabular}

Berdasarkan Tabel 2 tersebut terlihat bahwa skor minimal kemandirian belajar siswa dikelas eksperimen adalah 52 dan lebih tinggi dibandingkan dikelas kontrol yang skor minimalnya sebesar 48. Untuk skor maksimal kemandirian belajar siswa dikelas eksperimen adalah 96 dan lebih tinggi dibandingkan dikelas kontrol yang nilai maksimalnya sebesar 89 . Dengan demikian rerata kemandirian belajar siswa untuk kelas eksperimen sebesar 79,29 lebih tinggi dibandingkan siswa kelas kontrol yang reratanya sebesar 71,07. Simpangan baku kemandirian belajar siswa untuk untuk kelas eksperimen sebesar 13,42 lebih tinggi dibandingkan siswa kelas kontrol yang simpangan bakunya sebesar 11,96.

Pengujian hipotesis secara statistik dilakukan dengan menggunakan ANAVA dua jalur dilakukan setelah terpenuhinya syarat data yang berdistiribusi normal dan varians kelompok data yang homogen.

Berdasarkan hasil kemandirian belajar siswa maka dilakukan uji hipotesis berikut ini:

$H_{0}: \alpha_{1}=\alpha_{2}=\alpha_{3}=0$

$H_{1}$ : Paling sedikit ada satu $\alpha_{j}$ yang tidak nol

Statistik : $F_{\alpha}=\frac{R K A}{R K G}$

Daerah kritis $\quad: F_{\alpha}>F_{(0.05,2,48)}=3,19$

$H_{0}: \beta_{1}=\beta_{2}=0$

$H_{1}$ : Paling sedikit ada satu $\beta_{j}$ yang tidak nol

Statistik : $\quad F_{\beta}=\frac{R K B}{R K G}$

Daerah kritis $\quad: F_{\beta}>F_{(0.05,1,48)}=4,04$
$H_{0}:(\alpha \beta)_{i j}=0 ; i=1,2 ; j=1,2,3$

$H_{a}$ : minimal salah satu $(\alpha \beta)_{i j} \neq 0 ; i=1,2 ; j=1,2,3$

Statistik

Daerah kritis $\quad: F_{\alpha \beta}>F_{(0.05,2,48)}=3,19$

Adapun hasil uji hipotesis dengan uji ANAVA dua jalur menggunakan Program SPSS dideskripsikan pada Tabel 3 berikut ini:

Tabel 3. Hasil Uji Interaksi Antara Model Pembelajaran Dengan KAM

TerhadapKemandirian Belajar Siswa

\begin{tabular}{|c|c|c|c|c|c|}
\hline Sourca & $\begin{array}{c}\text { 7ype III Sun of } \\
\text { Scuares }\end{array}$ & & Mear Squsre & F & Sig. \\
\hline CcrrectedModel & $7771.750^{\circ}$ & 5 & 1554350 & 81.120 & .000 \\
\hline Inteccapt & 187485.526 & 1 & 187485326 & 5734.694 & .000 \\
\hline KALI & 6850.017 & 2 & $34250) \varepsilon$ & 178.743 & .000 \\
\hline Pembelkjarsn & 278.330 & 1 & $278.33 \mathrm{C}$ & 14.526 & .000 \\
\hline KALI ${ }^{*}$ embelajuran & 127.423 & 2 & 63.711 & 3.325 & .044 \\
\hline Encr & 915.732 & 43 & 19.161 & & \\
\hline Tctel & 316354.000 & 54 & & & \\
\hline Ccrrected Total & 8691.481 & 53 & & & \\
\hline
\end{tabular}

Berdasarkan Tabel 3 diatas terlihat bahwa untuk faktor pembelajaran diperoleh nilai $F_{\text {hitung }}$ sebesar 14,526 dan $F_{(0.05,1,48)}=4,04, \quad$ karena $F_{\alpha}>F_{(0.05,1,48)}=4,04$ maka tolak Ho dan terima Ha. Artinya, kategori faktor pembelajaran berpengaruh terhadap kemandirian belajar siswa. Dapat dilihat juga bahwa untuk faktor pembelajaran dengan KAM diperoleh nilai $F_{\text {hitung sebesar 3,325 dan }}$ $F_{(0.05,2,48)}=3,19 \quad$ karena $F_{\alpha \beta}>F_{(0.05,2,48)}=3,19$ maka tolak Ho dan terima Ha. Dengan demikian, bahwa terdapat interaksi antara model pembelajaran (blended learning berbasis masalah dan konvensional) dengan kemampuan awal matematika (KAM) terhadap kemandirian belajar siswa.Dengan demikian, dapat disimpulkan bahwa terdapat interaksi antara model pembelajaran (blended learning berbasis masalah dan konvensional) dengan kemampuan awal matematika (KAM) terhadap kemandirian belajar siswa. Hal ini dapat diartikan bahwa terdapat pengaruh bersama yang diberikan oleh model pembelajaran dan kemampuan awal matematika terhadap kemandirian belajar siswa.

Adapun hasil uji lanjut pasca anava dua jalur untuk kemandirian belajar siswa akan disajikan pada Tabel 4 berikut ini:

Tabel 4 Hasil Uji Lanjut ANAVA Dua Jalur Antara KAM dan Pembelajaran Terhadap Kemandirian Belajar Siswa

\begin{tabular}{|ll|r|r|r|r|}
\hline KAM & Pembelajaran & \multirow{2}{*}{ Mean } & Std. Error & \multicolumn{2}{|c|}{$95 \%$ Confidence Interval } \\
\cline { 5 - 6 } & & & & Lower Bound & Upper Bound \\
\hline \multirow{2}{*}{ Tinggi } & Eksperimen & 97.231 & 1.214 & 87.790 & 92.672 \\
& Kontrol & 87.583 & 1.264 & 78.043 & 83.124 \\
Sedang & Eksperimen & 73.727 & 1.320 & 71.074 & 76.381 \\
& Kontrol & 69.909 & 1.320 & 67.255 & 72.563 \\
& Eksperimen & 52.333 & 2.527 & 47.252 & 57.415 \\
Rendah & Kontrol & 49.750 & 2.189 & 45.349 & 54.151 \\
& &
\end{tabular}

Berdasarkan Tabel 4 maka dapat dideskripsikan pengujian hipotesis uji lanjut ANAVA dua jalur antara KAM dan pembelajaran terhadap kemandirian belajar siswa sebagai berikut ini: 
1. Terdapat perbedaan kemandirian belajar yang memiliki kemampuan awal matematika tinggi antara siswa yang diberi model blended learning berbasis masalah dan pembelajaran konvensional. Dengan rata-rata kemampuan awal matematika tinggi antara siswa yang diberi model blended learning berbasis masalah sebesar 90,231 dan rata-rata kemampuan awal matematika tinggi antara siswa yang diberi pembelajaran konvensional sebesar 80,583.

2. Terdapat perbedaan kemampuan pemecahan masalah yang memiliki kemampuan awal matematika sedang antara siswa yang diberi model blended learning berbasis masalah dan pembelajaran konvensional. Dengan rata-rata kemampuan awal matematika sedang antara siswa yang diberi model blended learning berbasis masalah sebesar 73,727 dan rata-rata kemampuan awal matematika sedang antara siswa yang diberi pembelajaran konvensional sebesar 69,909.

Terdapat perbedaan kemampuan pemecahan masalah yang memiliki kemampuan awal matematika rendah antara siswa yang diberi model blended learning berbasis masalah dan pembelajaran konvensional. Dengan rata-rata kemampuan awal matematika sedang antara siswa yang diberi model blended learning berbasis masalah sebesar 52,3 dan rata-rata kemampuan awal matematika rendah antara siswa yang diberi pembelajaran konvensional sebesar 49,75 .

\section{PEMBAHASAN}

Berdasarkan temuan penelitian dan hasil analisis data, akan dilihat hubungannya dengan tujuan penelitian yang telah ditetapkan. Pembahasan hasil penelitian akan diuraikan berdasarkan beberapa faktor yang terkait dalam penelitian ini, yakni faktor model pembelajaran, kemampuan pemecahan masalah, dan kemandirian belajar siswa dan interaksi model pembelajaran dengan kemampuan awal matematika terhadap kemampuan pemecahan masalah dan kemandirian belajar siswa.

\subsubsection{Faktor Model Pembelajaran}

Model pembelajaran merupakan salah satu faktor yang mempengaruhi kemampuan pemecahan masalah dan kemandirian belajar siswa. Setiap tahap pada model pembelajaran memiliki kontribusi terhadap kemampuan pemecahan masalah dan kemandirian belajar siswa. Dengan demikian, setiap tahap dalam model pembelajaran blended learning berbasis masalah diterapkan dalam pembelajaran di kelas eksperimen, dan pembelajaran konvensional diterapkan di kelas kontrol dengan harapan agar memperoleh hasil yang optimal.

Dalam penelitian ini proses pembelajaran pada masing-masing kelas, para peserta didik bekerja sama dalam kelompok-kelompok kecil. Hal tersebut didukung oleh teori belajar Vygotsky yang lebih memfokuskan perhatian kepada hubungan dialektika antar individu dalam pembentukan pengetahuan tersebut. Vygotsky memandang bahwa bahasa adalah pusat dalam proses belajar (Oakley, 2004). Adanya interaksi sosial dengan teman sebaya (tutor sebaya) atau bahkan dengan gurunya, akan mempengaruhi keterampilan komunikasi siswa dalam kelompok maupun dengan kelompok lain serta tanggung jawab bersama dalam kelompok dan dilengkapi dengan guru yang berperan sebagai motivator, fasilitator dan moderator akan memungkinkan diskusi yang lebih berkualitas dan pembelajaran yang lebih efektif.

Pada masing-masing kelas peneliti mengawali pembelajaran melalui adanya konflik kognitif, hal ini sejalan dengan teori belajar konstruktivisme.Karli dan Yuliariatiningsih (2000) menyatakan bahwa konflik kognitif ini hanya bisa diatasi melalui pengetahuan diri (self-regulation). Pada akhir proses belajar, pengetahuan akan dibangun sendiri oleh anak melalui pengalamannya dari hasil interaksi dengan lingkungannya. Selain itu pembelajaran mengutamakan pembelajaran bermakna, teori belajaran bermakna dari Ausubel menekankan pentingnya siswa mengasosiasikan pengalaman, fenomena, dan faktafakta baru ke dalam struktur kognitifnya. Keduanya menekankan pentingnya asimilasi pengalaman ke dalam struktur kognitif dan menkankan proses belajar adalah dengan cara siswa aktif.

Di samping itu, pembelajaran blended learning berbasis masalah mengutamakan pembelajaran memecahkan masalah. Hal ini sejalan dengan teori Bruner, yang memungkinkan siswa untuk menggunakan seluruh pengetahuan mereka (kognitif, afektif dan pshycomotor), terutama proses belajar untuk menentukan konsep atau atau prinsip oleh diri mereka sendiri dan melatih proses mental mereka yang merupakan karakteristik dari seorang ilmuwan (Pedaste et al, 2015) dan melatih keterampilan pemecahakan masalah siswa. Dalam kontekes penyelesaian masalah, siswa diberi suatu permasalahan dengan tujuan mendorong mereka untuk mencari tahu bagaimana cara mneyelesaikan permasalahan tersebut sehingga nantinya mereka bisa membuat suatu keismpulan dari permalsalahan tersebut. Dalam penyelesaian masalah, siswa terlibat langsung dalam kegiatan dan diskusi individu dan kelompok, dengan bantuan guru, siswa mengidentifikasi prakonsepsi.Dari pemahaman awal mereka, siswa bergerak maju dalam membangun pengetahuan baru dengan pengetahuan yang berpusat pada siswa dan mendorong serta merangsang pikiran siswa karena mereka perlu menggunakan keterampilan penalaran mereka untuk memecahkan masalah yang diberikan oleh guru dan kemudian membuat kesimpulan (Radzi et al., 2017).

Pembelajaran blended learning berbasis masalah merupakan pembelajaran yang menekankan pada situasi atau kondisi permasalahan yang nyata dan berkaitan dengan kehidupan sehari-hari siswa. Dengan 
penerapan Pembelajaran blended learning berbasis masalah dalam pembelajaran diharapkan siswa dapat lebih mudah memahami konsep apa yang sebenarnya ingin disampaikan, dan dapat pula mengembangkan pengetahuan siswa yang telah dimiliki menjadi lebih kompleks. Ketika siswa memiliki pengetahuan yang cukup akan materi yang dihadapi, dan siswa juga diberi kesempatan untuk menyampaikan apa yang dimilikinya.

Pembelajaran blended learning berbasis masalah ini pun didukung oleh pembelajaran $e$-learning yang mana siswa maupun guru dituntut untuk bisa menerapkan pembelajaran kombinasi, yaitu kombinasi pembelajaran secara tatap muka di kelas dan pembelajaran secara online dengan menggunakan aplikasi komputer yang tersambung dengan internet. Aplikasi yang digunakan dalam pembelajaran ini adalah moodle. Moodle (singkatan dari Modular Object-Oriented Dynamic Learning Environment) adalah paket perangkat lunak yang diproduksi untuk kegiatan belajar berbasis internet dan situs web yang menggunakan prinsip social constructionist pedagogy. Moodle merupakan salah satu aplikasi dari konsep dan mekanisme belajar mengajar yang memanfaatkan teknologi informasi, yang dikenal dengan konsep pembelajaran elektronik atau e-learning.

Moodle memiliki berbagai fasilitas yang dapat berguna mendukung kegiatan pembelajaran.Fasilitas yang terdapat pada Moodle antara lain Assignment, Chat, Forum, Quiz, dan Survey.Penjelasan untuk masing-masing fasilitas menurut Amiroh (2012) adalah sebagai berikut. 1) Assignment digunakan untuk memberikan penugasan kepada siswa secara online. Siswa dapat mengakses materi tugas dan mengumpulkan tugas dengan cara mengirimkan file hasil pekerjaan mereka. 2) Chat digunakan oleh guru dan siswa untuk saling berinteraksi secara online dengan cara berdialog teks (percakapan online). 3) Forum merupakan forum diskusi secara online antara guru dan siswa yang membahas topik-topik yang berhubungan dengan materi pembelajaran. 4) Quiz digunakan oleh guru untuk melakukan ujian tes secara online. 5) Survey digunakan untuk melakukan jajak pendapat.

\subsection{Kemandirian Belajar Siswa}

Penelitian yang dilakukan di SMP Swasta Imelda Medan ini melibatkan dua kelas yaitu kelas eksperimen pada kelas VIII A dan kelas kontrol pada kelas VIII B. Setelah diberikan perlakuan yang berbeda pada kelas eksperimen dan kelas kontrol, maka diberikan angket kemandirian belajar untuk mengetahui sejauh mana rasa kepercayaan diri siswa dalam mengikuti pembelajaran yang berlangsung. Angket kemandirian belajarini terdiri dari 20 butir pernyataan yang mengandung aspek dan indikator kemandirian belajar yaitu percaya diri, inisiatif belajar bertanggung jawab dan motivasi.
Berdasarkan hasil analisis data secara deskriptif setelah diberi perlakuan, kemandirian belajar siswa yang belajar dengan pembelajaran blended learning berbasis masalah lebih tinggi dari siswa yang belajar dengan pembelajaran konvensional. Hal ini ditunjukkan oleh rata-rata skor angket kemandirian belajar pada kelas eksperimen yaitu 80,64 sementara di kelas kontrol sebesar 67,41.

Berdasarkan penjelasan di atas, kemandirian belajarsiswa yang belajar melalui pembelajaran blended learning berbasis masalah lebih tinggi dibandingkan dengan siswa yang belajar dengan pembelajaran konvensional. Hasil tersebut dianalisis dengan ANAVA dua jalur dan dapat disimpulkan bahwa terdapat perbedaaan kemandirian belajar siswa melalui pembelajaran blended learning berbasis masalah dengan pembelajaran konvensional.

Hal ini dipengaruhi bahwa pembelajaran blended learning berbasis masalah lebih mampu menekankan pada situasi atau kondisi permasalahan yang nyata dan berkaitan dengan kehidupan sehari-hari siswa. Dengan penerapan pembelajaran blended learning berbasis masalah dalam pembelajaran diharapkan siswa dapat lebih mudah memahami konsep apa yang sebenarnya ingin disampaikan, dan dapat pula mengembangkan pengetahuan siswa yang telah dimiliki menjadi lebih kompleks. Ketika siswa memiliki pengetahuan yang cukup akan materi yang dihadapi, dan siswa juga diberi kesempatan untuk menyampaikan apa yang dimilikinya sehingga siswa lebih percaya diri dalam mengikuti pembelajaran di kelas.

\subsection{Interaksi Antara Model Pembelajaran dengan Kemampuan Awal Matematika terhadap Kemandirian Belajar Siswa}

Berdasarkan hasil analisis statistik inferensial dengan uji ANAVA dua jalur pada baris kemampuan awal matematika*faktor pembelajaran diperoleh nilai $F_{\text {hitung }}$ sebesar 3,325 dan $\mathrm{F}_{(0.05,2,48)}=3,19$ karena $F_{\alpha \beta}>F_{(0.02,2,48)}=3,19$, maka dapat disimpulkan bahwa terdapat interaksi antara model pembelajaran (pembelajaran blended learning berbasis masalah dan konvensional) dengan kemampuan awal matematika terhadap kemandirian belajar siswa.

Dalam hal ini, model pembelajaran blended learning berbasis masalah dan konvensional berbeda hasil nya jika dilaksanakaan pada anak yang memiliki KAM sedang dan tinggi, tetapi tidak demikian halnya jika diberikan kepada siswa yang memiliki KAM rendah. Sejalan dengan pendapat Asy'ari dan Nonong (2018) menyatakan bahwa pada kategori kemandirian belajar siswa yang memiliki kemampuan awal matematika tinggi, sedang dan rendah antara model pembelajaran CTL dan model pembelajaran problem posing memberikan rata-rata yang sama, sedangkan kategori kemandirian belajar siswa yang memiliki kemampuan awal matematika tinggi, sedang dan rendah antara model pembelajaran CTL dan model 
pembelajaran problem posing memberikan rata-rata lebih baik daripada model pembelajaran konvensional.

Dengan adanya pengaruh interaksi, tidak dapat disimpulkan secara langsung bahwa salah satu model pembelajaran lebih baik dari pada yang lainnya.Untuk itu diperlukan uji lanjut terhadap data kemampuan pemecahan masalah siswa.Dari hasil uji lanjut diperoleh bahwa terdapat perbedaan yang signfikan antara kedua rerata kemampuan pemecahan masalah siswa dari kedua pembelajaran.Hal ini dikarenakan perbedaan terhadap tahapan pembelajaran dari kedua model pembelajaran.pada model pembelajaran blended learning berbasis masalah akan tertarik dengan proses pemecahan masalah sehingga pemahamannya akan bertahan lebih lama, sedangkan pada pembelajaran konvensionalsiswa lebih mengandalkan guru untuk memperoleh informasi.

\section{KESIMPULAN}

1. Terdapat perbedaan kemandirian belajar siswa yang diberi model pembelajaran blended learning berbasis masalah dengan siswa yang diberi pembelajaran konvensional. Rata-rata kemandirian belajar siswa (tinggi, sedang dan rendah) akan berbeda jika diberi perlakuan yang berbeda.

2. Terdapat interaksi antara model (blended learning berbasis masalah dan pembelajaran konvensional) dan kemampuan awal matematika terhadap kemandirian belajar siswa. Hal ini juga diartikan bahwa interaksi antara model (blended learning berbasis masalah dan pembelajaran konvensional) dan kemampuan awal matematika telah memberikan pengaruh secara bersama-sama terhadap kemandirian belajar siswa.

\section{REFERENSI}

Carman, J.M. 2005. Blended Learning Design: Five Key Ingredients [Online] Available: http://www.agilantlearning.com/pdf/Blended $\% 20$ Learning\%-20Design.pdf [Accesed 20 Agustus 2018]

Chaplin, J. P. 2002. Kamus Psikologi. (Terjemahan : Kartono). Jakarta: Raja Grafindo Persada

Fauzi, A. 2011. Peningkatan Kemampuan Koneksi Matematis dan Kemandirian Belajar Siswa dengan Pendekatan Pembelajaran Metakognitif di Sekolah Menengah Pertama. Proceedings of International Seminar and The Fourth National Conference on Mathematics Education "Building the Nation Character through Humanistic Mathematics Education". Departement of Mathematics Education, Yogyakarta State University, Yogyakarta, July 21-23: 109-122

Hendriana, Heris, Euis Eti Rohaeti dan Utari Sumarmo. 2017. Hard Skills dan Soft Skills Matematik Siswa. Bandung: PT. Refika Aditama
Jumaisyaroh, T,. E. E. Napitupulu, dan Hasratuddin. 2014. Peningkatan Kemampuan Berpikir Kritis Matematis dan Kemandirian Belajar Siswa SMP Melalui Pembelajaran Berbasis Masalah. Jurnal Kreano. ISSN 2086-2334 Vol 5 No2.

Lestari, K. E dan M. R. Yudhanegara. 2015. Penelitian Pendidikan Matematika. Bandung: PT. Refika Aditama

Russefendi, E.T. 2006. Pengantar Kepada Membantu Guru Mengembangkan Kompetensinya Dalam Pengajaran Matematika Untuk Meningkatkan CBSA. Bandung : Tarsito.

Trianto. 2009. Model-Model Pembelajaran Inoovatif Berorentasi Kontruktivistik Konsep, Landasan Teoritik Praktis dan Implementasinya. Jakarta: Prestasi Pustak0061

Whitelock, D. \& Jelfs, A.. 2003. "Editorial. Special Issue on Blended Learning". Journal of Educational Media. Vol. 28, No. 2, p.99-100. 